\title{
Genetic polymorphism of CYP17 and breast cancer risk in Korean women
}

\author{
Myung-Hee Shin ${ }^{1}$, Kyoung-Mu Lee ${ }^{2}$, \\ Jung-Hyun Yang ${ }^{3}$, Seok Jin $\mathrm{Nam}^{3}$, \\ Jong-Won $\mathrm{Kim}^{4}$, Keun-Young $\mathrm{YoO}^{2}$, \\ Sue Kyung Park ${ }^{5}$, Dong-Young Noh ${ }^{6}$, \\ Sei-Hyun Ahn ${ }^{7}$, Bongcheol $\mathrm{Kim}^{8}$ \\ and Daehee Kang ${ }^{2,9}$
}

\author{
${ }^{1}$ Department of Social and Preventive Medicine \\ Sungkyunkwan University School of Medicine \\ 300 Chunchun-dong, Changan-gu, Suwon \\ Kyungi-do 440-746, Korea \\ ${ }^{2}$ Department of Preventive Medicine \\ Seoul National University College of Medicine \\ Cancer Research Institute \\ ${ }^{3}$ Department of Surgery \\ ${ }^{4}$ Department of Clinical Pathology \\ Samsung Medical Center \\ Sungkyunkwan University School of Medicine \\ 50 Ilwon-dong, Kangnam-gu, Seoul 135-230 \\ ${ }^{5}$ Departments of Preventive Medicine \\ Konkuk University College of Medicine \\ 322 Danwol-dong, Chungju \\ Chuncheongbuk-do 380-701, Korea \\ ${ }^{6}$ Departments of General Surgery \\ Seoul National University College of Medicine \\ Cancer Research Institute \\ 28 Yongon-dong, Chongno-gu, Seoul 110-799, Korea \\ ${ }^{7}$ Department of Surgery \\ Ulsan University College of Medicine \\ 388-1 Pungnab-dong, Songpa-gu, Seoul 138-736, Korea \\ ${ }^{8}$ Pan Genomics, Co., Ltd. \#304 \\ Biotechnology Incubating Center \\ Seoul National Univeristy \\ Kwanak-gu, Seoul 151-742, Korea \\ ${ }^{9}$ Corresponding author: Tel, 82-2-740-8326; \\ Fax, 82-2-747-4830; E-mail, dhkang@snu.ac.kr
}

Accepted 17 December 2004

Abbreviations: aOR, age-adjusted OR; $\mathrm{BMI}$, body mass index; $\mathrm{Cl}$, confidence interval; CYP17, cytochrome P450C17 $\alpha$; mOR, multivariate $\mathrm{OR}$; UTR, untranslated region

\author{
Abstract \\ CYP17 gene is involved in steroidogenesis and \\ steroid metabolism. Epidemiologic results on
}

the association between the CYP17 polymorphism and breast cancer risk have been inconsistent. We examined the association between the MspAl polymorphism at +27 relative to the start of transcription in the 5'-untranslated region of CYP17 gene and breast cancer risk in Korean women. Four hundred and sixty-two incident cases and 337 controls were recruited from three teaching hospitals in Seoul during 1994-2001. Polymorphism of the CYP17 gene was determined by a single base extension assay. Demographic and lifestyle characteristics were identified using structured questionnaire. Age-adjusted (aOR) and multivariate odds ratios (mOR) and $95 \%$ confidence intervals (CI) were estimated by unconditional logistic regression. The proportions of A1/A1, A1/A2 and A2/A2 genotypes among controls were $20.8 \%, 45.1 \%$ and $34.1 \%$, respectively. Compared to the A1/A1 genotype, A1/A2 or A2/A2 genotype was not statistically significantly associated with overall breast cancer risk (i.e., $\mathrm{mOR}=1.01,95 \% \mathrm{CI}=$ $0.69-1.47$ and $\mathrm{mOR}=0.76,95 \% \mathrm{Cl}=0.51-1.14$, re spectively). However, a significant association between CYP17 A2/A2 genotype and breast cancer was observed among women aged 50 years or less (mOR $=0.58,95 \% \mathrm{Cl}=0.34-0.99, P=0.04$ ) and leaner women (body mass index $<22 \mathrm{~kg} /$ $\left.\mathrm{m}^{2}\right)(\mathrm{mOR}=0.48,95 \% \mathrm{Cl}=0.23-0.97, P=0.04)$. Our results suggest that genetic polymorphism in 5'-untranslated region of CYP17 might play a role in breast cancer development in Korean women among younger women aged less than 50 or leaner women with body mass index less than $22 \mathrm{~kg} / \mathrm{m}^{2}$.

Keywords: breast neoplasms; estrogens; genotype; genetic polymorphism; steroid hydroxylases

\section{Introduction}

Higher level of endogenous estrogens is strongly associated with the risk of breast cancer (Hankinson et al., 1998), and the level of endogenous estrogens is known to be regulated by the pathway of steroidogenesis in which many enzymes are involved. Recent interest has been focused on polymorphisms in genes that control the metabolism or intracellular transport 
of sex hormones (Dunning et al., 1999).

CYP17 gene codes for one of the key enzymes, cytochrome P450c17 $\alpha$ (CYP17) which catalyzes the conversion of 17-hydroxypregnenolone to 17-hydroxyprogesterone or dehygroepiandrosterone (DHEA) to androstenedione in the synthesis of estrogen. Thus, genetic polymorphism of CYP17 could change the expression levels or activities of the cytochrome $\mathrm{P} 450 \mathrm{C} 17 \alpha$ and, in turn, the risk of breast cancer in relation with the changes in estrogen biosynthesis. A polymorphism of $\mathrm{T} \rightarrow \mathrm{C}$ substitution in $5^{\text {'-untranslated }}$ region (UTR) of CYP17 gene creates MspAI restriction site (denoted as $A 1 / A 2$ ) and has also been suggested to create a promoter motif to transcription factor, Sp-1 (CCACC box) (Carey et al., 1994). This polymorphism at +27 relative to the start of transcription, has a potential to enhance the promotor activity and production rate of CYP17, and eventually the levels of endogenous steroid hormones (Feigelson et al., 1998; Haiman et al., 1999).

A number of epidemiological studies have evaluated the potential role of CYP17 polymorphism in breast cancer development (Feigelson et al., 1997; Dunning et al., 1998; Helzlsouer et al., 1998; Weston et al., 1998; Bergman-Jungestrom et al., 1999; Huang et al., 1999; Hamajima et al., 2000; Kuligina et al., 2000; Mitrunen et al., 2000; Miyoshi et al., 2000; Spurdle et al., 2000; Ambrosone et al., 2003; Cui et al., 2003; Wu et al., 2003; Hefler et al., 2004) since the first association study (Feigelson et al., 1997) reported that A2 carriers had 2.5-fold higher risk of advanced breast cancer in a nested case-control study of multiethnic cohort. However, the results for the association between CYP17 polymorphism and breast cancer risk have been inconsistent. Several studies have found a positive association between A2/A2 genotype and the risk of breast cancer in the subgroups such as younger (22-36 years old) Sweden (Bergman-Jungestrom et al., 1999), younger $(<40)$ Australian (Spurdle et al., 2000) and older ( $\geq 55)$ Japanese (Miyoshi et al., 2000). However, most other studies could not reproduce the positive association between A2/A2 genotype and breast cancer risk; e.g., no association was found in studies conducted for Caucasians in UK (Dunning et al., 1998), US (Weston et al., 1998; Haiman et al., 1999; Ambrosone et al., 2003), Finland (Mitrunen et al., 2000), hispanics and African-Americans in US (Weston et al., 1998), Japanese (Hamajima et al., 2000), Chinese in Singapore (Wu et al., 2003) and Taiwanese (Huang et al., 1999).

These inconsistent results might be due to relatively small sample size, and ethnic diversity which comprises the difference in allele frequency, exposure to risk factor of breast cancer risk and the others. It is known that Asian women have higher variant allele (A2) than Caucasians (Miyoshi et al., 2000). Those studies investigating the relationship between A2/A2 genotype and breast cancer risk for Asian population included less than two hundred breast cancer cases and showed inconsistent results (Huang et al., 1999; Hamajima et al., 2000; Miyoshi et al., 2000; Wu et al., 2003). Additionally, most association studies have been conducted for Caucasian population, so far. Therefore, in this study, the association between the $\mathrm{T} \rightarrow \mathrm{C}$ polymorphism in the 5'-UTR of the CYP17 gene and breast cancer risk was evaluated in Korean population in a larger case-control study.

\section{Materials and Methods}

\section{Subjects}

Subjects were recruited from three teaching hospitals in Seoul during 1994-2001. Eligible subjects consisted of incident breast cancer cases with histological confirmation $(n=577)$ and controls with non-cancer diseases $(n=507)$ in the same hospitals from whom blood samples were available. After women with previous history of cancer, hysterectomy or oophorectomy and whose DNA samples with small amount were excluded, a total of 462 cases and 337 control subjects were included in the final analysis. The diseases of controls included infection or stone of gall bladder/bile duct, benign breast disease, acute appendicitis, hemorrhoid, hernia/ perforation, lipoma, and the others.

The study design was approved by the Committee on Human Research of Seoul National University Hospital, and the subjects provided their informed consents prior to participation in the study. Information on demographic characteristics and other known risk factors of breast cancer was obtained using a structured questionnaire administered by trained interviewers as described in detail previously (Lee et al., 2004).

\section{Genotyping}

DNA was extracted using standard methods from blood drawn into $10 \mathrm{ml}$ heparinized tubes and stored at $-20^{\circ} \mathrm{C}$ until use. A1/A2 polymorphism of the CYP17 was determined by the single base extension assay (SnapShot). The PCR products were obtained by using $500 \mathrm{nM}$ of oligonucleotide primers (P1: 5'-TTT CCA CAA GGC AAG AGA TAA CA-3' and P2: 5'GGA GGC TCT TGG GGT ACT-3') in a total volume of $20 \mu \mathrm{l}$ of reaction mixture. The amplification profile consisted of initial denaturation at $95^{\circ} \mathrm{C}$ for $5 \mathrm{~min}$ followed by 35 cycles of $30 \mathrm{~s}$ at $94^{\circ} \mathrm{C}, 60 \mathrm{~s}$ of $54^{\circ} \mathrm{C}$ and $120 \mathrm{~s}$ at $72^{\circ} \mathrm{C}$.

Primer extension reaction was performed by combining $1 \mu \mathrm{l}$ of exonuclease I and alkaline phosphatase treated PCR product with $5 \mu \mathrm{l}$ SNaPshot kit (including DNA polymerase, fluorescently labeled ddNTPs, and control primers), 0.15 pmol extension primer (5'TTGCCACAGCTCTTCTACTCCAC-3') and $3 \mu$ water. The reaction mixture was incubated at $94^{\circ} \mathrm{C}$ for $2 \mathrm{~min}$ and followed by 25 cycles of $95^{\circ} \mathrm{C}$ for $5 \mathrm{~s}, 50^{\circ} \mathrm{C}$ for $5 \mathrm{~s}$ and $60^{\circ} \mathrm{C}$ for $5 \mathrm{~s}$. Aliquots of $1 \mu \mathrm{l}$ single base extension product and $9 \mu \mathrm{Hi}-\mathrm{Di}$ formamide were combined in a 96-well 3100 optical microamp plate, which was loaded onto a 3100 DNA sequencer (Applied Biosystems, Foster City, CA). Electrophoresis data were processed by Genescan Analysis version 3.7 (Applied Biosystems, Foster City, CA). 


\section{Statistical analysis}

Age-adjusted (aOR) and multivariate odds ratios (mOR) and $95 \%$ confidence intervals $(\mathrm{Cl})$ were estimated by unconditional logistic regression. In the multivariate analysis, the ORs were adjusted for age at diagnosis, family history of breast cancer, history of benign disease, history of hypertension, breast feeding for 12 months or more, and the duration of education for more than 9 years.

Hardy-Weinberg equilibrium test was performed for the genotype distribution in the controls for evaluating possible selection bias and genotyping errors.

To evaluate the dominant effect of gene variation, heterozygous and homozygous variants were combined into one genotype group. Possible effect modification by other risk factors such as age, body mass index (BMI), and family history of breast cancer was evaluated by stratified analyses.

\section{Results}

The mean age of the 462 breast cancer cases and 337 controls was $47.6( \pm 10.5)$ and $47.3( \pm 14.5)$, respectively (t-test: $P=0.63$ ). Cases and controls were significantly different in terms of the family history of breast cancer, past history of benign breast disease, history of hypertension, history of breast feeding for 12 months or more, and the duration of education for nine or more years (Table 1).

Among controls, the proportions of CYP17 A1/A1, $A 1 / A 2$ and $A 2 / A 2$ genotypes were $20.8 \%, 45.1 \%$ and $34.1 \%$, respectively (Table 2 ). This genotype distribution did not diverge significantly from Hardy-Weinberg equilibrium $(P=0.14)$. There was no difference among the genotype distributions by the hospitals from which the subjects were recruited $\left(\chi^{2}\right.$-test: $P=$ 0.22).

Compared with the A1/A1 genotype, A1/A2 or A2/A2 genotype was not statistically significantly as-

Table 1. Characteristics of breast cancer cases $(n=462)$ and controls $(n=337)$.

\begin{tabular}{|c|c|c|c|c|c|c|}
\hline & \multicolumn{2}{|c|}{ Cases } & \multicolumn{2}{|c|}{ Controls } & \multirow{2}{*}{ OR $(95 \% \quad C l)^{a}$} & \multirow{2}{*}{$P$-value } \\
\hline & $\mathrm{N}$ & $\%$ & $\mathrm{~N}$ & $\%$ & & \\
\hline Age $\leq 50$ yrs old & 303 & 65.6 & 207 & 61.4 & $0.84(0.62-1.12)$ & 0.23 \\
\hline Postmenopausal & 181 & 39.2 & 147 & 43.6 & $0.83(0.63-1.11)$ & 0.21 \\
\hline Age at menarche $\leq 13$ yrs old & 57 & 12.3 & 45 & 13.5 & $0.90(0.59-1.37)$ & 0.64 \\
\hline Family history of breast cancer & 44 & 9.5 & 11 & 3.3 & $3.08(1.57-6.06)$ & $<0.01$ \\
\hline History of benign breast disease & 19 & 4.1 & 1 & 0.3 & $14.4(1.9-107.9)$ & $<0.01$ \\
\hline History of hypertension & 26 & 5.6 & 35 & 10.4 & $0.52(0.30-0.87)$ & 0.01 \\
\hline Number of full term pregnancy $\leq 1$ & 98 & 21.2 & 86 & 25.5 & $0.79(0.56-1.09)$ & 0.15 \\
\hline Breast feeding $\geq 12$ months & 251 & 54.7 & 209 & 62.2 & $0.73(0.55-0.98)$ & 0.03 \\
\hline Body mass index $\geq 25 \mathrm{~kg} / \mathrm{m}^{2}$ & 109 & 23.8 & 68 & 20.9 & $1.19(0.84-1.67)$ & 0.33 \\
\hline Duration of education $\geq 9 \mathrm{yrs}$ & 307 & 66.5 & 180 & 53.4 & $1.73(1.03-2.31)$ & $<0.01$ \\
\hline
\end{tabular}

${ }^{a}$ Crude odds ratio (95\% confidence interval).

Table 2. The association between CYP17 genotypes and breast cancer risk.

\begin{tabular}{|c|c|c|c|c|c|c|c|c|}
\hline \multirow{2}{*}{ Genotypes of } & \multicolumn{2}{|c|}{ Cases } & \multicolumn{2}{|c|}{ Controls } & \multirow{2}{*}{ aOR $(95 \% \quad C l)^{a}$} & \multirow{2}{*}{$P$-value } & \multirow{2}{*}{$\operatorname{mOR}(95 \% \quad \mathrm{Cl})^{\mathrm{b}}$} & \multirow{2}{*}{$P$-value } \\
\hline & $\mathrm{N}$ & $\%$ & $\mathrm{~N}$ & $\%$ & & & & \\
\hline $\mathrm{A} 1 / \mathrm{A} 1$ & 112 & 24.2 & 70 & 20.8 & 1.00 (reference) & & 1.00 (reference) & \\
\hline $\mathrm{A} 1 / \mathrm{A} 2$ & 223 & 48.3 & 152 & 45.1 & $0.92(0.64-1.32)$ & 0.85 & $1.01(0.69-1.47)$ & 0.97 \\
\hline $\mathrm{A} 2 / \mathrm{A} 2$ & 127 & 27.5 & 115 & 34.1 & $0.69(0.47-1.02)$ & 0.05 & $0.76(0.51-1.14)$ & 0.19 \\
\hline$P_{\text {trend }}$ & & & & & 0.05 & & 0.15 & \\
\hline$A 1 / A 2+A 2 / A 2$ & 350 & 75.8 & 267 & 79.2 & $0.82(0.59-1.15)$ & 0.25 & $0.90(0.63-1.28)$ & 0.56 \\
\hline
\end{tabular}

${ }^{a}$ Adjusted for age. ${ }^{b}$ Adjusted for age at diagnosis, family history of breast cancer, history of benign disease, history of hypertension, breast feeding for 12 months or more, and the duration of education for more than 9 yrs. 
sociated with overall breast cancer risk (i.e., $\mathrm{mOR}=$ $1.01,95 \% \mathrm{Cl}=0.69-1.47, P=0.97$ for $\mathrm{A} 1 / \mathrm{A} 2$ genotype, and $\mathrm{mOR}=0.76,95 \% \mathrm{Cl}=0.51-1.14, P=0.19$ for A2/A2 genotype).

However, the inverse association was mildly strengthened among younger women. Compared to A1/A1 genotype, A2/A2 genotype had an inverse association among women aged 50 years or less (A2/A2 vs. $\mathrm{A} 1 / \mathrm{A} 1, \mathrm{aOR}=0.54,95 \% \mathrm{Cl}=0.32-0.90, \mathrm{mOR}=0.58$, $95 \% \mathrm{Cl}=0.34-0.99, P=0.04)$, and the risk decreased as the number of $\mathrm{A} 2$ allele increased $\left(P_{\text {trend }}=0.04\right)$ (Table 3). Among women aged more than 50, there was no association between A2/A2 genotype and breast cancer risk. The inverse association was also mildly pronounced in leaner women $\left(B M I<22 \mathrm{~kg} / \mathrm{m}^{2}\right.$ ) $(\mathrm{A} 2 / \mathrm{A} 2$ vs. $\mathrm{A} 1 / \mathrm{A} 1, \quad \mathrm{OOR}=0.44,95 \% \mathrm{Cl}=0.23-0.83$ and $\mathrm{mOR}=0.48,95 \% \mathrm{Cl}=0.23-0.97)$, and the decreasing trend of breast cancer risk was significant in that group $\left(P_{\text {trend }}=0.03\right)$ (Table 4$)$.

The presence of A2 allele was not associated with other hormone related risk factors for breast cancer, such as age at menarche and age at menopause
(Table 5).

\section{Discussion}

Our results suggest that genetic polymorphism of CYP17 might play a role in breast cancer development in Korean women especially among the subgroup of younger women $(\leq 50)$ or leaner women $\left(\mathrm{BMI}<22 \mathrm{~kg} / \mathrm{m}^{2}\right.$ ).

In agreement with the majority of the previous epidemiological studies on the association between CYP17 polymorphism and breast cancer risk, this study did not reveal significant association between the CYP17 A2 allele and overall risk of breast cancer. However, an inverse association between A2/A2 genotype and breast cancer risk among women aged 50 years or less was observed in this study. Although earlier studies reported a positive association between A2 allele and breast cancer risk, an inverse, though not significant, association was suggested in the studies conducted by Weston et al. (1998), Hamajima et

Table 3. The association between CYP17 genotypes and breast cancer risk by age group.

\begin{tabular}{|c|c|c|c|c|c|c|c|c|}
\hline \multirow{2}{*}{ Genotypes } & \multicolumn{4}{|c|}{ Age $\begin{array}{l}\leq 50 \text { yrs old } \\
n=510\end{array}$} & \multicolumn{4}{|c|}{ Age $\begin{array}{l}>50 \text { yrs old } \\
n=289\end{array}$} \\
\hline & $\begin{array}{l}\text { Case/ } \\
\text { Control }\end{array}$ & $\begin{array}{c}\text { aOR } \\
(95 \% \quad \mathrm{Cl})^{\mathrm{a}}\end{array}$ & $\begin{array}{c}\text { mOR } \\
(95 \% \quad \mathrm{Cl})^{b}\end{array}$ & $P$-value ${ }^{c}$ & $\begin{array}{l}\text { Case/ } \\
\text { Control }\end{array}$ & $\begin{array}{c}\text { aOR } \\
(95 \% \quad \mathrm{Cl})^{\mathrm{a}}\end{array}$ & $\begin{array}{c}\mathrm{mOR} \\
(95 \% \quad \mathrm{Cl})^{\mathrm{b}}\end{array}$ & $P$-value ${ }^{c}$ \\
\hline $\mathrm{A} 1 / \mathrm{A} 1$ & $77 / 37$ & 1.00 (reference) & 1.00 (reference) & & $35 / 33$ & 1.00 (reference) & 1.00 (reference) & \\
\hline $\mathrm{A} 1 / \mathrm{A} 2$ & $142 / 94$ & $0.77(0.48-1.25)$ & $0.81(0.49-1.33)$ & 0.40 & $81 / 58$ & $1.34(0.74-2.42)$ & $1.51(0.82-2.81)$ & 0.19 \\
\hline $\mathrm{A} 2 / \mathrm{A} 2$ & $84 / 76$ & $0.54(0.32-0.90)$ & $0.58(0.34-0.97)$ & 0.04 & $43 / 39$ & $1.07(0.56-2.06)$ & $1.12(0.57-2.22)$ & 0.74 \\
\hline$P_{\text {trend }}$ & & 0.01 & 0.04 & & & 0.89 & 0.83 & \\
\hline $\mathrm{A} 1 / \mathrm{A} 2+\mathrm{A} 2 / \mathrm{A} 2$ & $226 / 170$ & $0.67(0.43-1.04)$ & $0.71(0.44-1.13)$ & 0.14 & $124 / 97$ & $1.23(0.71-2.14)$ & $1.35(0.76-2.41)$ & 0.31 \\
\hline
\end{tabular}

${ }^{a}$ Adjusted for age. ${ }^{b}$ Adjusted for age at diagnosis, family history of breast cancer, history of benign disease, history of hypertension, breast feeding for 12 months or more, and the duration of education for more than $9 \mathrm{yrs}$. ${ }^{~} P$-value for mOR.

Table 4. The association between CYP17 genotypes and breast cancer risk by body mass index (BMI).

\begin{tabular}{|c|c|c|c|c|c|c|c|c|}
\hline \multirow{2}{*}{ Genotypes } & \multicolumn{4}{|c|}{$\begin{array}{c}\text { BMI }<22 \mathrm{~kg} / \mathrm{m}^{2} \\
n=303\end{array}$} & \multicolumn{4}{|c|}{ BMI $\underset{n=496}{\geq 22 \mathrm{~kg} / \mathrm{m}^{2}}$} \\
\hline & $\begin{array}{l}\text { Case/ } \\
\text { Control }\end{array}$ & $\begin{array}{c}\text { aOR } \\
(95 \% \quad \mathrm{Cl})^{\mathrm{a}}\end{array}$ & $\begin{array}{c}\mathrm{mOR} \\
(95 \% \quad \mathrm{Cl})^{\mathrm{b}}\end{array}$ & $P$-value ${ }^{c}$ & $\begin{array}{l}\text { Case/ } \\
\text { Control }\end{array}$ & $\begin{array}{c}\text { aOR } \\
(95 \% \quad \mathrm{Cl})^{\mathrm{a}}\end{array}$ & $\begin{array}{c}\mathrm{mOR} \\
(95 \% \quad \mathrm{Cl})^{\mathrm{b}}\end{array}$ & $P$-value \\
\hline $\mathrm{A} 1 / \mathrm{A} 1$ & $47 / 25$ & 1.00 (reference) & 1.00 (reference) & & $65 / 45$ & 1.00 (reference) & 1.00 (reference) & \\
\hline $\mathrm{A} 1 / \mathrm{A} 2$ & $86 / 52$ & $0.88(0.48-1.59)$ & $0.89(0.46-1.73)$ & 0.72 & $137 / 100$ & $0.95(0.60-1.50)$ & $1.04(0.65-1.67)$ & 0.87 \\
\hline $\mathrm{A} 2 / \mathrm{A} 2$ & $42 / 51$ & $0.44(0.23-0.83)$ & $0.48(0.23-0.97)$ & 0.04 & $85 / 64$ & $0.92(0.56-1.52)$ & $1.02(0.61-1.71)$ & 0.94 \\
\hline$P_{\text {trend }}$ & & 0.007 & 0.03 & & & 0.76 & 0.96 & \\
\hline $\mathrm{A} 1 / \mathrm{A} 2+\mathrm{A} 2 / \mathrm{A} 2$ & $128 / 103$ & $0.66(0.38-1.14)$ & $0.70(0.37-1.30)$ & 0.25 & $222 / 164$ & $0.94(0.61-1.45)$ & $1.03(0.66-1.61)$ & 0.89 \\
\hline
\end{tabular}

${ }^{a}$ Adjusted for age. ${ }^{b}$ Adjusted for age at diagnosis, family history of breast cancer, history of benign disease, history of hypertension, breast feeding for 12 months or more, and the duration of education for more than 9 yrs. ${ }^{~} P$-value for mOR. 
Table 5. The association between selective risk factors for breast cancer and CYP17 genotypes among controls.

\begin{tabular}{|c|c|c|c|c|}
\hline \multirow{2}{*}{ Selective risk factors } & & \multicolumn{2}{|c|}{ Frequency (\%) } & \multirow{2}{*}{$P$-value ${ }^{a}$} \\
\hline & & $\mathrm{A} 1 / \mathrm{A} 1(\%)$ & $\mathrm{A} 1 / \mathrm{A} 2+\mathrm{A} 2 / \mathrm{A} 2(\%)$ & \\
\hline \multirow[t]{2}{*}{ Age } & $\leq 50$ & $37(52.9)$ & $170(63.7)$ & 0.10 \\
\hline & $>50$ & $33(47.1)$ & $97(36.3)$ & \\
\hline \multirow[t]{2}{*}{ Family history of breast cancer } & No & $69(98.6)$ & $253(96.2)$ & $0.47^{b}$ \\
\hline & Yes & $1(1.4)$ & $10(3.8)$ & \\
\hline \multirow[t]{2}{*}{ Duration of education } & $<9$ yrs & $37(52.9)$ & $120(44.9)$ & 0.24 \\
\hline & $\geq 9$ yrs & $33(47.1)$ & $147(55.1)$ & \\
\hline \multirow[t]{2}{*}{ Duration of breast feeding } & $<12$ months & $24(34.3)$ & $103(38.7)$ & 0.50 \\
\hline & $\geq 12$ months & $46(65.7)$ & $163(61.3)$ & \\
\hline \multirow[t]{2}{*}{ Age at first full term pregnancy } & $\leq 25$ yrs old & $36(59.0)$ & $109(46.6)$ & 0.08 \\
\hline & $>25$ yrs old & $25(41.0)$ & $125(53.4)$ & \\
\hline \multirow[t]{2}{*}{ Number of full term pregnancy } & $\leq 1$ & $59(84.3)$ & $192(71.9)$ & 0.03 \\
\hline & $>1$ & $11(15.7)$ & $75(28.1)$ & \\
\hline \multirow[t]{2}{*}{ Age at menarche } & $>13$ yrs old & $62(88.6)$ & $227(86.0)$ & 0.57 \\
\hline & $\leq 13$ yrs old & $8(11.4)$ & $37(14.0)$ & \\
\hline \multirow[t]{2}{*}{ Menopause } & No & $34(48.6)$ & $156(58.4)$ & 0.14 \\
\hline & Yes & $36(51.4)$ & $111(41.6)$ & \\
\hline \multirow[t]{2}{*}{ Body mass index } & $<22 \mathrm{~kg} / \mathrm{m}^{2}$ & $23(33.8)$ & $94(36.4)$ & 0.69 \\
\hline & $\geq 22 \mathrm{~kg} / \mathrm{m}^{2}$ & $45(66.2)$ & $164(63.6)$ & \\
\hline
\end{tabular}

${ }^{a}$ From Pearson's $\chi^{2}$-test; ${ }^{b}$ From Fisher's exact test.

al. (2000) and Mitrunen et al. (2000). The trend of inverse association has also been reported among Asian women in a recent meta-analysis for 15 casecontrol studies (Ye et al., 2002).

The associations between A2/A2 genotype and the breast cancer risk in younger women and leaner women in this study suggest the possibility of hormonal involvement in the development of breast cancer. Most subjects under the age of 50 were premenopausal women whose baseline level of exposure to estrogen is higher than postmenopausal women. It is speculated that obese women have more anovulatory menstrual cycles, which in turn results in lower circulatory progesterone and estradiol levels (Cleary et al., 1997).

Several studies suggested that $\mathrm{T} \rightarrow \mathrm{C}$ polymorphism of CYP17 gene would increase the hormonal production and thus the risk of breast cancer: the level of circulating estrogens was higher in women with A2 allele than A1 allele (Feigelson et al., 1998; Haiman et al., 1999; Miyoshi et al., 2003). However, the effect of this polymorphism on the level of estrogen is still controversial. Kristensen et al. (1999) could not verify this hypothesis, i.e., a recombinant $\mathrm{Sp}-1$ protein which combined with human embryonic $\varepsilon$-globin gene did not combine with the created site of the CC-genotype in vitro. Likewise, Tworoger et al., (2004) found no association between CYP17 genotype and estrogen concentrations in serum and urine.
In present study, hormone related factors, such as age at menarche or age at menopause was not related to A2 allele. Whether A2 allele is associated with lower level of estrogens in Korean women remains to be investigated in future studies.

One of other findings is the ethnic diversity of genotype distributions of CYP17 gene. Proportion of A2/A2 among Korean women in this study (34.1\%) was higher than that of Caucasian population (8-17\%) (Dunning et al., 1998; Helzlsouer et al., 1998; Weston et al., 1998; Bergman-Jungestrom et al., 1999; Haiman et al., 1999; Young et al., 1999; Ambrosone et al., 2000; Kuliginal et al., 2000; Mitrunen et al., 2000; Spurdle et al., 2000; Feigelson et al., 2001; Cui et al., 2003; Hefler et al., 2004). The frequencies of A2/A2 among other Asian populations were $28 \%$ for Taiwanese (Huang et al., 1999), 16-21\% for Japanese (Hamajima et al., 2000; Miyoshi et al., 2000) and 34\% for Singapore Chinese (Wu et al., 2003).

Our study has several limitations such as hospital based study, relatively small sample sizes in subgroup analysis, and evaluation for only one polymorphism in CYP17 without evident genotype-phenotype relationship etc. Thus, the results of this study should be interpreted with caution and suggestive effect of CYP17 A2/A2 genotype observed in this study need to be evaluated in a well designed study with more statistical power.

In conclusion, in this study, a suggestive effect of 
A2/A2 genotype of CYP17 gene was observed only among the subgroup of younger and leaner women in Korean population. However, further studies with more comprehensive genotyping and evaluation of genotype-phenotype relationship need to be conducted.

\section{Acknowledgement}

This research was supported by grant No. R01-2000000-00184 and R01-2001-000-00162-0 from the Korea Science and Engineering Foundation.

\section{References}

Ambrosone $\mathrm{CB}$, Moysich $\mathrm{KB}$, Furberg $\mathrm{H}$, Freudenheim $\mathrm{JL}$, Bowman ED, Ahmed S, Graham S, Vena JE, Shields PG. CYP17 genetic polymorphism, breast cancer, and breast cancer risk factors. Breast Cancer Res 2003;5:R45-51

Carey AH, Waterworth D, Patel K, White D, Little J, Novelli $P$, Franks S, Williamson R. Polycystic ovaries and premature male pattern baldness are associated with one allele of the steroid metabolism gene CYP17. Hum Mol Genet 1994;3: 1873-6

Cleary MP, Maihle NJ. The role of body mass index in the relative risk of developing premenopausal versus postmenopausal breast cancer. Proc Soc Exp Biol Med 1997;216: $28-43$

Cui JS, Spurdle $A B$, Southey MC, Dite GS, Venter DJ, McCredie MRE, Giles GG, Chenevix-Trench G, Hopper JL. Regressive logistic and proportional hazards disease models for within-family analyses of measured genotypes, with application to a CYP17 polymorphism and breast cancer. Genet Epidemiol 2003;24:161-72

Dunning AM, Healey CS, Pharoah PD, Foster NA, Lipscombe JM, Redman KL, Easton DF, Day NE, Ponder BA. No association between a polymorphism in the steroid metabolism gene CYP17 and risk of breast cancer. $\mathrm{Br} J$ Cancer 1998;77:2045-7

Dunning AM, Healey CS, Pharoah PDP, Tear MD, Ponder BAJ, Easton DFA. Systematic review of genetic polymorphisms and breast cancer risk. Cancer Epidemiol Biomark Prev 1999;8:843-54

Feigelson HS, Coetzee GA, Kolonel LN, Ross RK, Henderson BE. A polymorphism in the CYP17 gene increases the risk of breast cancer. Cancer Res 1994;57:1063-5

Feigelson HS, Shames LS, Pike MC, Coetzee GA, Stanczyk FZ, Henderson BE. Cytochrome P450c17alpha gene (CYP17) polymorphism is associated with serum estrogen and progesterone concentrations. Cancer Res 1998;58:585-7

Haiman CA, Hankinson SE, Spiegelman D, Colditz GA, Willett WC, Speizer FE, Kelsey KT, Hunter DJ. The relationship between a polymorphism in CYP17 with plasma hormone levels and breast cancer. Cancer Res 1999;59: $1015-20$

Hamajima N, Iwata H, Obata $\mathrm{Y}$, Matsuo K, Mizutani M, Iwase T, Miura S, Okuma K, Ohashi K, Tajima K. No association of the $5^{\prime}$ promoter region polymorphism of CYP17 with breast cancer risk in Japan. Jpn J Cancer Res 2000;91:880-5

Hankinson SE, Willett WC, Manson JE, Colditz GA, Hunter DJ, Spiegelman D, Barbieri RL, Speizer FE. Plasma sex steroid hormone levels and risk of breast cancer in postmenopausal women. J Natl Cancer Inst 1998;90:1292-9

Hefler LA, Tempfer CB, Grimm C, Lebrecht A, Ulbrich E, Heinze G, Leodolter S, Schneeberger C, Mueller MWW, Muendlein A, Koelbl H. Estrogen-metabolizing gene polymorphisms in the assessment of breast carcinoma risk and fibroadenoma risk in Caucasian women. Cancer 2004;101: 264-9

Helzlsouer KH, Huang HY, Strickland PT, Hoffman S, Alberg AH, Comstock GW, Bell DA. Association between CYP17 polymorphisms and the development of breast cancer. Cancer Epidemiol Biomarkers Prev 1998;7:945-9

Huang CS, Chern HD, Chang KJ, Cheng CW, Hsu SM, Shen $\mathrm{CY}$. Breast cancer risk associated with genotype polymorphism of the estrogen-metabolizing genes CYP17, CYP1A1, and COMT: a multigenic study on cancer susceptibility. Cancer Res 1999;59:4870-5

Kristensen VN, Haraldsen EK, Anderson KB, Lonning PE, Erikstein B, Karesen R, Gabrielsen OS, Borrensen-Dale A. CYP17 and breast cancer risk: The polymorphism in the $5^{\prime}$ flanking area of the gene does not influence binding to Sp-1. Cancer Res 1999;59:2825-8

Kuligina ES, Togo AV, Suspitsin EN, Grigoriev MY, Pozharisskiy KM, Changunava OL, Berstein LM, Theillet C, Hanson KP, Imyanitov EN. CYP17 polymorphism in the groups of distinct breast cancer susceptibility: comparison of patients with the bilateral disease vs. monolateral breast cancer patients vs. middle-aged female controls vs. elderly tumor-free women. Cancer Lett 2000;156:45-50

Lai J, Vesprini D, Chu W, Jernstrom $H$, Narod SA. CYP gene polymorphisms and early menarche. Mol Genet Metab 2001;74:449-57

Lee SA, Kang D, Nishio H, Lee MJ, Kim DH, Han W, Yoo $\mathrm{KY}$, Ahn SH, Choe KJ, Hirvonen A, Noh DY. Methylenetetrahydrofolate reductase polymorphism, diet, and breast cancer in Korean women. Exp Mol Med 2004;36:116-21

Miyoshi Y, Iwao K, Ikeda N, Egawa C, Noguchi S. Genetic polymorphism in CYP17 and breast cancer risk in Japanese women. Eur J Cancer 2000;36:2375-9

Miyoshi Y, Ando A, Ooka M, Shiba E, Taguchi T, Tamaki Y, Noguchi S. Association of CYP17 genetic polymorphism with intra-tumoral estradiol concentrations but not with CYP17 messenger RNA levels in breast cancer tissue. Caner Lett 2003;195:81-6

Mitrunen K, Jourenkova $\mathrm{N}$, Kataja V, Eskelinen M, Kosma VM, Benhamou S, Vainio H, Uusitupa M, Hirvonen A. Steroid metabolism gene CYP17 polymorphism and the development of breast cancer. Cancer Epidemiol Biomarkers Prev 2000; 9:1343-8

Nedelcheva Kristensen V, Haraldsen EK, Anderson KB, Lonning PE, Erikstein B, Karesen R, Gabrielsen OS, Borresen-Dale AL. CYP17 and breast cancer risk: the polymorphism in the 5'-flanking area of the gene does not influence binding to Sp-1. Cancer Res 1999;59:2825-8 
Spurdle AB, Hopper JL, Dite GS, Chen X, Cui J, McCredie MR, Giles GG, Southey MC, Venter DJ, Easton DF, Chenevix-Trench G. CYP17 promoter polymorphism and breast cancer in Australian women under age forty years. J Natl Cancer Inst 2000;92:1674-81

Tworoger SS, Chubak J, Aiello EJ, Ulrich CM, Atkinson C, Potter JD, Yasui Y, Stapleton PL, Lampe JW, Farin FM, Stanczyk FZ, McTiernan A. Association of CYP17, CYP19, CYP1B1, and COMT polymorphisms with serum and urinary sex hormone concentrations in postmenopausal women. Cancer Epidemiol Biomarkers Prev 2004;13:94-101
Weston A, Pan CF, Bleiweiss IJ, Ksieski HB, Roy N, Maloney N, Wolff MS. CYP17 genotype and breast cancer risk. Cancer Epidemiol Biomarkers Prev 1998;7:941-4

Wu AH, Seow A, Arakawa K, van den berg D, Lee HP, Yu MC. HSD171B1 and CYP17 polymorphisms and breast cancer risk among Chinese women in Singapore. Int $\mathrm{J}$ Cancer 2003;104:450-7

Ye Z, Parry JM. The CYP17 MspA1 polymorphism and breast cancer risk: a meta-analysis. Mutagenesis 2002;17: $119-26$ 